\title{
Some Observations on Indian Federalism in Comparative Perspective
}

\author{
Mauro Mazza \\ Law Department, University of Bergamo, Bergamo, Italy \\ Email: mauro.mazza@unibg.it
}

Received 30 December 2014; accepted 15 February 2015; published 17 February 2015

Copyright @ 2015 by author and Scientific Research Publishing Inc.

This work is licensed under the Creative Commons Attribution International License (CC BY). http://creativecommons.org/licenses/by/4.0/

(c) (i) Open Access

\begin{abstract}
The article analyses the form of state of the federal Indian Union, which is rather atypical in the "landscape" of comparative constitutional law. The trend towards centralization of functions and powers, both at federal and state levels, probably constitutes some sort of quasi-federalism, or semi-federalism, or even unionist federalism. Indian pragmatic federalism, which we can mainly characterize as a variant of ethnic federalism, may well lead, in terms of the classification of the forms of state, to consider Indian federalism as unitary federalism, or as the realization of a sui generis unionist state.
\end{abstract}

\section{Keywords}

Forms of State, Indian Federalism, Unionist Federalism, Ethnic Regionalism

\section{Introduction: The Indian Federalism, between Colonial Legacy and Foreign Models of Ethnic Federalism}

You must be the change you wish to see in the world.

Mahātmā Ghandi (Verna, 2010: p. 3).

The Indian federalism, whose essential characteristics are outlined in the provisions contained in the Articles 1-11 of the Constitution of Indian Union that came into force in January 1950, can be defined as an atypical and sui generis federalism, especially for the weak political decentralization (Acquarone, 2006; Amirante, 2007; Amirante, 2010; Amirante, 2013a; Amirante, 2013b; Amirante, 2014; Amirante, Decaro, \& Pföstl, 2013; Dell'Aquila \& Dell'Aquila, 2010; Francavilla, 2010; Lingat, 1967; Sacco, 2011). It must also be noted that not all levels of government have the same powers and responsibilities, with the result that in the federal Indian architecture both symmetric and asymmetric elements coexist. The overall picture seems to be dominated by a kind of adaptation of federalism to India. If, then, we can observe a trend towards centralization at the federal 
level, it is also accompanied by centralization at the state level. The issue of citizenship, in turn, introduces unique elements of India's federal system. Citizenship, in fact, is provided only at the union level, as shown by Articles 5-10 of the Federal Constitution, and the constitutional choice is reitered in the Citizenship Act of 1955. It follows a pattern of ethnic federalism, reminiscent of what happened in Eastern Europe during the socialist period, and in the Soviet Union itself. In fact, if we examine the characteristics of the Czechoslovak public law, the Yugoslav constitutional law and, above all, the Soviet constitutional system, we find the traces of ethnic federalism, based on the creation of a federation that has the main purpose of keeping within the boundaries of the federal state a plurality of peoples, each of which with different languages, customs and even different legal rules. On the other hand, in the Soviet Union, the citizenship was only federal, despite the fact that the opposition to this institutional solution was sometimes raised, particularly on the part of the Baltic Republics, not surprisingly the first to definitively separate themselves from the USSR in 1991 (Mazza, 2013a; Mazza, 2013b; Mazza, 2013c; Taube, 2001).

We also need to note that this approach, implemented by the Indian Federal Constitution, is not entirely coincident with the idea of federation supported by the founder of the Indian Union, namely Ghandi. The latterwhich had, in addition to the disciples, many friends, but also some opponents (Pföstl, 2014: p. 147)—wanted to give more power to the basic representative institutions, and in particular to the village councils; moreover, he thought to create not a federation but rather a confederation, to reduce the functions of the central power. The strengthening of the basic assemblies or councils, on the other hand, was linked to the characteristics of the same British colonialism, founded as it is known on the organizational model of the indirect rule, as opposed (more in law in books that in the law in action) to the model of direct rule of French colonial tradition, founded on the paradigm of assimilation (in the same way, from this point of view, of the model of colonialism developed by a smaller colonial power, namely the Italian colonialism, which realized a synthesis between the British system of indirect rule and the French direct colonial government, while the Italian colonial sub-model standed closer to the second than the first). It can, therefore, be noted that the Indian federalism has some common elements, in terms of historical legal system, with the multi-ethnic federalism of socialist countries of Eastern Europe, and also has set itself, at least in the "Gandhian version", in a line of incomplete break with the past experience of British colonialism, which has manifested itself not only in India but also mainly in Africa, with regard to the realization of the pattern of indirect rule (Mazza, 2009).

\section{Indian Federalism? Some Thoughts on Quasi-Federalism, Semi-Federalism, Unionist Federalism, Ethnic Regionalism}

In the federal India the Act of Parliament may create other states, and also change the names and the consistency of the states themselves. From this point of view, the characteristics of a unitary and autonomous system are emerging, i.e. not exactly those of a federal state. From here, the improper meaning of Indian federalism, which can be called "quasi-federal". If, therefore, we reflect on comparative models of political and administrative decentralization, at one extreme we find the unitary state, then the regional state and, continuing, the form of state that give more powers to local decentralized authorities decentralized, i.e. the federal state (Mazza, 2010). Additionally, before you get to the type of confederation, which marks the transition from constitutional to international law, it is perhaps possible to place the "marginal" model of the unionist state, the latter model of which the Indian Union would be a potential examples.

The historical path that led to the creation of the Indian Federation confirms the impression of an atypical federalism, or rather of a unionist federalism. Already the Government of India Act of 1935 proposed the creation of a federal system in India, with the territorial subdivisions called provinces, but also with the recognition of a strong central power. This project has not reached the stage of approval. Later, when it was discussed in India about the form to give to the independent state, the proposal to create a federal structure was put forward in 1947 by the Committee of the Constitution of the Union, but in the form of the so-called new federalism, characterized in particular by the presence of a strong central power, as well as by the allocation of residual powers, in relation to the exercise of legislative power, not to the federated states but instead to the Federation. It is clear that, in this way, we are far from the model of federalism in the United States of America, in which-as it is well know - the residual legislative powers are attributed to the Member States of the Federation. On the other hand, the constitutional comparative scholars are used, in the study of classification of models, to believe that the allocation of the residual legislative powers to member states is an essential characteristics of federal states. 
With regard to Italy, we must not forget that the new Article 117 of the Constitution, after the constitutional revision of 2001-currently subject to reconsideration (Bin, 2012), gives to the regions the residual legislative powers, and it is because of this institutional feature that some Italian scholars (Ferrari, 2006; Mazza, 2012) talk of new regionalism, or advanced regionalism (in the absence of other institutional features that usually are considered typical of the federalism, such as the presence of the Federal Senate, as well as the necessary participation of the member states to the procedure for constitutional amendment, or even the adoption by the member states of their own constitution, which also includes a catalog of rights, the so-called bill of rights).

In terms of comparison, the fact that the Indian Federal Parliament may-as mentioned above - change the size of a state or the name of the states, and also limit, in accordance with the Federal Constitution, the legislative or executive powers of a Member State, certainly put the Indian federalism far from the US federalism. In the US, in fact, the autonomy of the Member States, although it cannot be qualified under the term of sovereignty, is anyway strongly guaranteed against the powers of the Federation. Those who think, therefore, about the classification of the Indian federal model, must necessarily make use of the formulas of the "quasi-federalism" and "semi-federalism", unless you want even opt for the definition of the Indian system as unfederal. In truth, proper elements of the federal model and elements that belong to the advanced unitary model seem to coexist; hence, the methodological proposal of the possible classification of the Indian Union in the new model of the unionist state. Of course, it remains also open the possibility to qualify the Indian Union just like a model of ethnic regionalism. In this sense, after all, was the most qualified Italian legal doctrine (Biscaretti di Ruffìa \& Crespi Reghizzi, 1979; Ganino, 2003; Filippini, 2004) when it reflected on the classification of the Soviet constitutional model.

\section{Some Additional Considerations, in Comparison with (Sub-Saharan) African (Ethnic) Federalisms, to Support the View of Indian Pragmatic Federalism}

Moving to another area of the legal globe, and now focusing on sub-Saharan Africa-with the exception of the South African federalism, whose evolution has been characterized by the need to overcome the apartheid regime (Orrù, 1998; Orrù, 2012), we find more interesting evidence to support the hypothesis of the (post-colonial) Indian federalism as a variant of federalism, or even as ethnic regionalism. The Federal Constitution of Ethiopia, adopted in 1994 (Mattei, 1995), is usually referred to as the case of the implementation of ethnic federalism, as aiming especially to keep within the boundaries of Ethiopia the plurality of the peoples who live in it, including in particular the Amhara (Ge'ez: 'Äməhära, i.e. the traditionally dominant ethnic group), the Oromo and the Tigray people. Even the federal (or quasi-federal) constitutions of independent Nigeria have been approved in order to keep within the Federation the various ethnic groups, especially the Yoruba, Igbo and Hausa-Fulani, the so-called big three (Abegunde, 2013; Montinari, 1999; Omotoso, 2010). From here, also, the large recognition of the linguistic rights of the various ethnic groups, as it is done on the basis of both Article 345 of the Indian Constitution (Poggeschi, 2013: p. 169), so that the states of the Indian Union can be defined as "linguistic states" (Amirante, 2012), and Article 54 of the Ethiopian Constitution (Mazza, 2008: p. 180). It is true that, in India, the linguistic pluralism is in addition to religious pluralism (Parashar, 2013), but it is no less true that in Nigeria the ethno-federal power sharing is strongly influenced, especially in its practical application, by the persistent religious conflict (Kendhammer, 2013; Miles, 2003).

The Indian federalism, ultimately, is a pragmatic federalism. In any case, the characterization of the Indian federalism as an unitary federalism is very strong. This is evidenced in the first place by the division of legislative powers, since-as noted above - the residual powers are attribuited to the Federation, and not to the Member States, in accordance with the provisions of Article 245 of the Federal Constitution. In other words, the powers of the states are clearly defined in the Constitution with respect to the powers of the Union, but the distribution is definitely to the advantage of the powers of the central authorities. Neither this occurs only at the level of legislative powers. From the point of view of the distribution of executive powers, the role of the institutions of the Union is prevalent. Suffice it to say that it is the competence of the President of the Union to designate the twenty-six judges of the Supreme Court, on a proposal made by the Federal Government, and also the appointment of judges of the High Courts, though in the latter case the President need to consulte not only the Chief Justice of the Supreme Court, but also the Chief Justice of the High Court and the Governor of the State concerned. On the other hand, still falls within the powers of the Federal Government the declaration of a state of emergency, in accordance with Articles 352 and 360 of the Federal Constitution. 


\section{Conclusion: The Forms of State and Classification Criteria, in the Light of Indian Federalism}

Article 1 of the Federal Constitution states very clearly that India is a Union of States. Taking account of legislative and administrative powers of both the Federation and the Member States, it is moving from the notion of a Union of States that must be found the correct systematic classification of the Indian Union between the forms of the state, so as to mitigate the relevance of the discussion on the possibility of classifying the Union itself along the lines of a federal or quasi-federal form of the state. The problem of classifying the forms of state in comparative perspective should certainly be considered in the light of the historical development of legal systems, and also of the dynamics and tensions that often characterize federal systems (Pinelli, 2009; Volpi, 2013)_taking also into account that the study of the forms of state, along with that of the forms of government, decentralization and constitutional justice, still represent the core of the reflections of the constitutionalists comparatists (Pegoraro, 2013; Pegoraro, 2104: p. 143), but in any case the example of the Indian Union seems one of the most important to demonstrate that, in the sphere of federal systems, there are cases of border, which are almost beyond the precise insertion into the established legal categories, just to push up the interpreter to be tempted to move forward the flag of knowledge, and so identify Indian Union as one of the main representatives of the new legal category of the unionist state.

The conclusion regarding the systematic classification as well as the operational scheme of the Indian federalism therefore remains substantially open. And in fact, if we think that the Constitution of the Indian Union can be changed, except in some cases, without necessarily involving a large part of the Member States, and also that the constitutional bodies of the Union may legislate on matters reserved to Member States in the event of emergency situations or in relation to issues of national interest, and that the Union can still dissolve and replace the organs of the Federated States on grounds relating to national security, who can never say with absolute certainty and intellectual honesty that the Indian Union is not in reality, if not a unitary state, at least a regional advanced State?

\section{References}

Abegunde, O. (2013). Varianti e difficoltà del federalismo in Nigeria. Il Federalista. Rivista di Politica, 54-69.

Acquarone, L. (2006). Tra Dharma, Common Law e WTO. Un'Introduzione al Sistema Giuridico dell'India. Milano: CUEM.

Amirante, D. (2007). India. Bologna: Il Mulino.

Amirante, D. (2010). “Altre” Democrazie. Problemi e Prospettive del Consolidamento Democratico nel Sub-Continente Indiano. Milano: Angeli.

Amirante, D. (2012). Nation Building through Constitutionalism: Lessons from the Indian Experience. Hong Kong Law Journal, 42, 23-42.

Amirante, D. (2013a). Post-Modern Constitutionalism in Asia: Perspectives from the Indian Experience. National University of Juridical Sciences (NUJS) Law Review, 6, 213-229.

Amirante, D. (2013b). Il caleidoscopio del diritto indiano: Percorsi di comparazione. Annuario di Diritto Comparato e di Studi Legislativi, 239-259.

Amirante, D. (2014). L’India. In P. Carrozza, A. Di Giovine, \& G. F. Ferrari (Eds.), Diritto Costituzionale Comparato (Vol. I, p. 411). Roma-Bari: Laterza.

Amirante, D., Decaro, C., \& Pföstl, E. (2013). La Costituzione dell’Unione Indiana. Profili Introduttivi. Torino: Giappichelli.

Bin, R. (2012). La crisi delle Regioni: Che fare? Le Regioni, 735-749.

Biscaretti di Ruffìa, P., \& Crespi Reghizzi, G. (1979). La Costituzione sovietica del 1977. Un sessantennio di evoluzione costituzionale nell'URSS. Milano: Giuffrè.

Dell'Aquila, E., \& Dell'Aquila, L. (2010). Induismo e Buddismo nel diritto tradizionale dell'India. Udine: C.D.C. (Published with the Support of the Faculty of Political Science of the University of Pavia).

Ferrari, G. F. (2006). Federalismo, regionalismo e decentramento del potere in una prospettiva comparata. Le Regioni, 589648.

Filippini, C. (2004). Dall'Impero russo alla Federazione di Russia. Elementi di continuità e di rottura nell'evoluzione dei rapporti centro-periferia. Milano: Giuffrè.

Francavilla, D. (2010). Il diritto nell'India contemporanea. Sistemi tradizionali, modelli occidentali e globalizzazione. 
Torino: Giappichelli.

Ganino, M. (2003). I nodi del federalismo russo. In M. P. Viviani Schlein, E. Bulzi, \& L. Panzeri (Eds.), L'Europa tra federalismo e regionalismo (p. 207). Milano: Giuffrè.

Kendhammer, B. (2013). The Sharia Controversy in Northern Nigeria and the Politics of Islamic Law in New and Uncertain Democracies. Comparative Politics, 45, 291-311. http://dx.doi.org/10.5129/001041512X13815255434898

Lingat, R. (1967). La tradizione giuridica dell'India. Dharma, diritto e interpretazione. Milano: Giuffrè.

Mattei, U. (1995). The New Ethiopian Constitution: First Thoughts on Ethnical Federalism and the Reception of Western Institutions. In E. Grande (Ed.), Transplants, Innovation and Legal Tradition in the Horn of Africa (p. 111). Torino: L'Harmattan Italia.

Mazza, M. (2008). La tutela delle minoranze etniche nelle esperienze federali dell’Africa subsahariana. Nomos, 161-188.

Mazza, M. (2009). Premesse definitorie sul diritto coloniale comparato. Diritto Pubblico Comparato ed Europeo, 487-501.

Mazza, M. (2010). Stati federali, regionali, unitari. In G. F. Ferrari (Ed.), Atlante di Diritto Pubblico Comparato (p. 142). Torino: Utet.

Mazza, M. (2012). Federalismo, regionalismo e decentramento nella prospettiva della comparazione tra i sistemi di amministrazione (o governo) locale. Istituzioni del Federalismo, 829-856.

Mazza, M. (2013a). La Costituzione dell’Estonia (1992). In M. Ganino (Ed.), Codice delle Costituzioni (Vol. III, p. 47). Torino: Giappichelli.

Mazza, M. (2013b). La Costituzione della Lettonia (1922). In M. Ganino (Ed.), Codice delle Costituzioni (Vol. III, p. 87). Torino: Giappichelli.

Mazza, M. (2013c). La Costituzione della Lituania (1992). In M. Ganino (Ed.), Codice delle Costituzioni (Vol. III, p. 111). Torino: Giappichelli.

Miles, W. (2003). Shari’a as “De-Africanization”: Evidence from Hausaland. Africa Today, 50, 51-75. http://dx.doi.org/10.1353/at.2003.0061

Montinari, S. (1999). Nigeria: Questione etnica e soluzioni costituzionali. In M. Carducci (Ed.), Il costituzionalismo "parallelo" delle nuove democrazie. Africa e America Latina (p. 63). Milano: Giuffrè.

Omotoso, F. (2010). Theory and Practice of Federalism: The Nigerian Perspective. Ado-Ekiti: University of Ado-Ekiti.

Orrù, R. (1998). La Costituzione di tutti. Il Sudafrica dalla segregazione razziale alla democrazia della "rainbow nation”. Torino: Giappichelli.

Orrù, R. (2012). L’ordine costituzionale sudafricano post-apartheid: Luci ed ombre nell'orizzonte dei BRICS. In L. Scaffardi (Ed.), BRICs: Paesi emergenti nel prisma del diritto comparato (p. 101). Torino: Giappichelli.

Parashar, A. (2013). Religious Personal Laws as Non-State Laws: Implications for Gender Justice. Journal of Legal Pluralism and Unofficial Law, 45, 5-23. http://dx.doi.org/10.1080/07329113.2013.773804

Pegoraro, L. (2013). Le categorie civilistiche e il parassitismo metodologico dei costituzionalisti nello studio del diritto comparato. Annuario di Diritto Comparato e di Studi Legislativi, 305-335.

Pegoraro, L. (2014). Diritto costituzionale comparato. La scienza e il metodo. Bologna: Bononia University Press.

Pföstl, E. (2014). Between Ethics and Politic. Gandhi Today. New Delhi: Routledge.

Pinelli, C. (2009). Forme di Stato e forme di governo. Corso di diritto costituzionale comparato. Napoli: Jovene.

Poggeschi, G. (2013). Language Rights and Duties in the Evolution of Public Law. Baden-Baden: Nomos. http://dx.doi.org/10.5771/9783845249490

Sacco, R. (2011). Il diritto indiano. In A. Gambaro, \& R. Sacco (Eds.), Sistemi Giuridici Comparati (p. 363). Torino: UTET.

Taube, C. (2001). Constitutionalism in Estonia, Latvia and Lithuania. A Study in Comparative Constitutional Law. Uppsala: Iustus.

Verna, R. (2010). Be the Change. Teacher, Activist, Global Citizen. New York: Lang.

Volpi, M. (2013). Libertà e autorità. La classificazione delle forme di Stato e delle forme di governo. Torino: Giappichelli. 
Scientific Research Publishing (SCIRP) is one of the largest Open Access journal publishers. It is currently publishing more than 200 open access, online, peer-reviewed journals covering a wide range of academic disciplines. SCIRP serves the worldwide academic communities and contributes to the progress and application of science with its publication.

Other selected journals from SCIRP are listed as below. Submit your manuscript to us via either submit@scirp.org or Online Submission Portal.
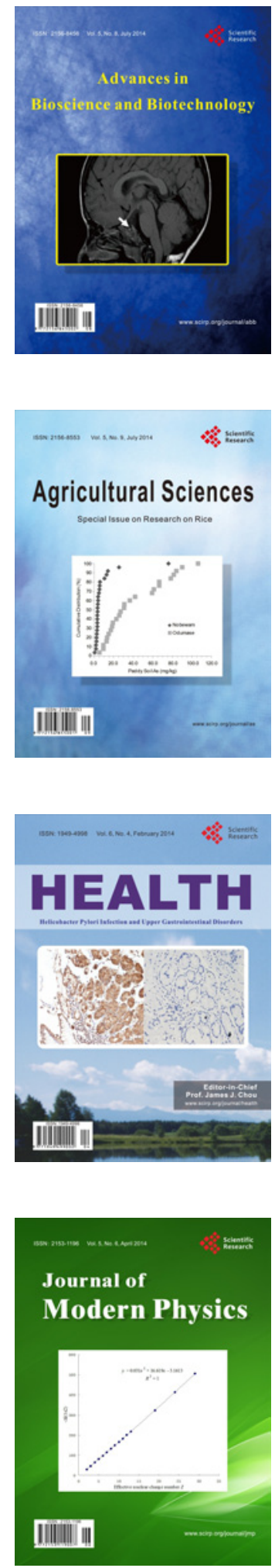
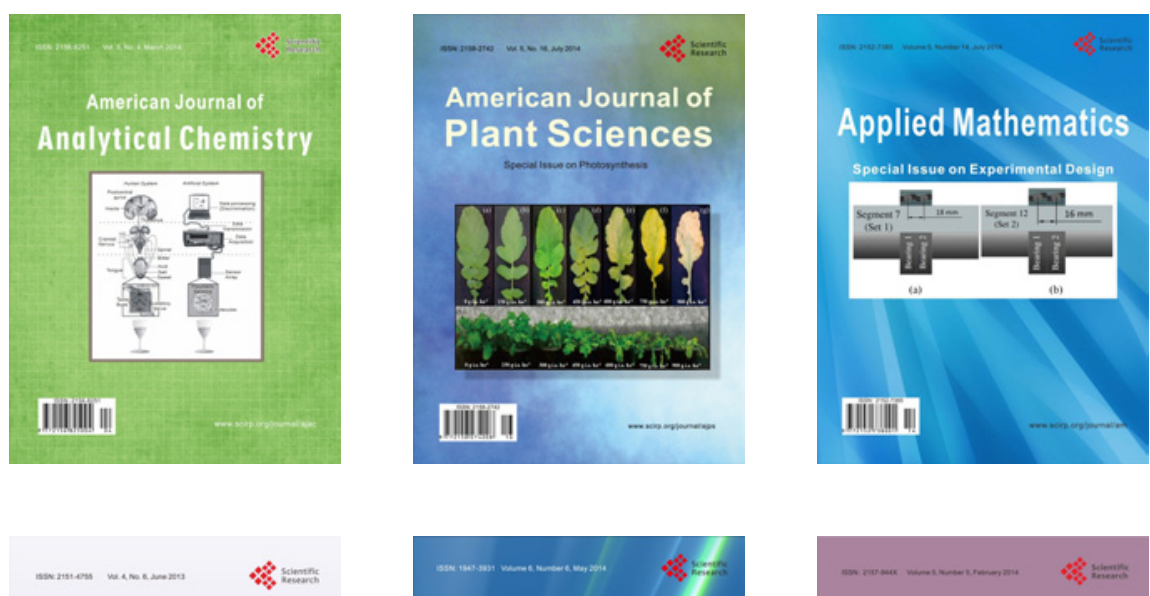

Creative Education
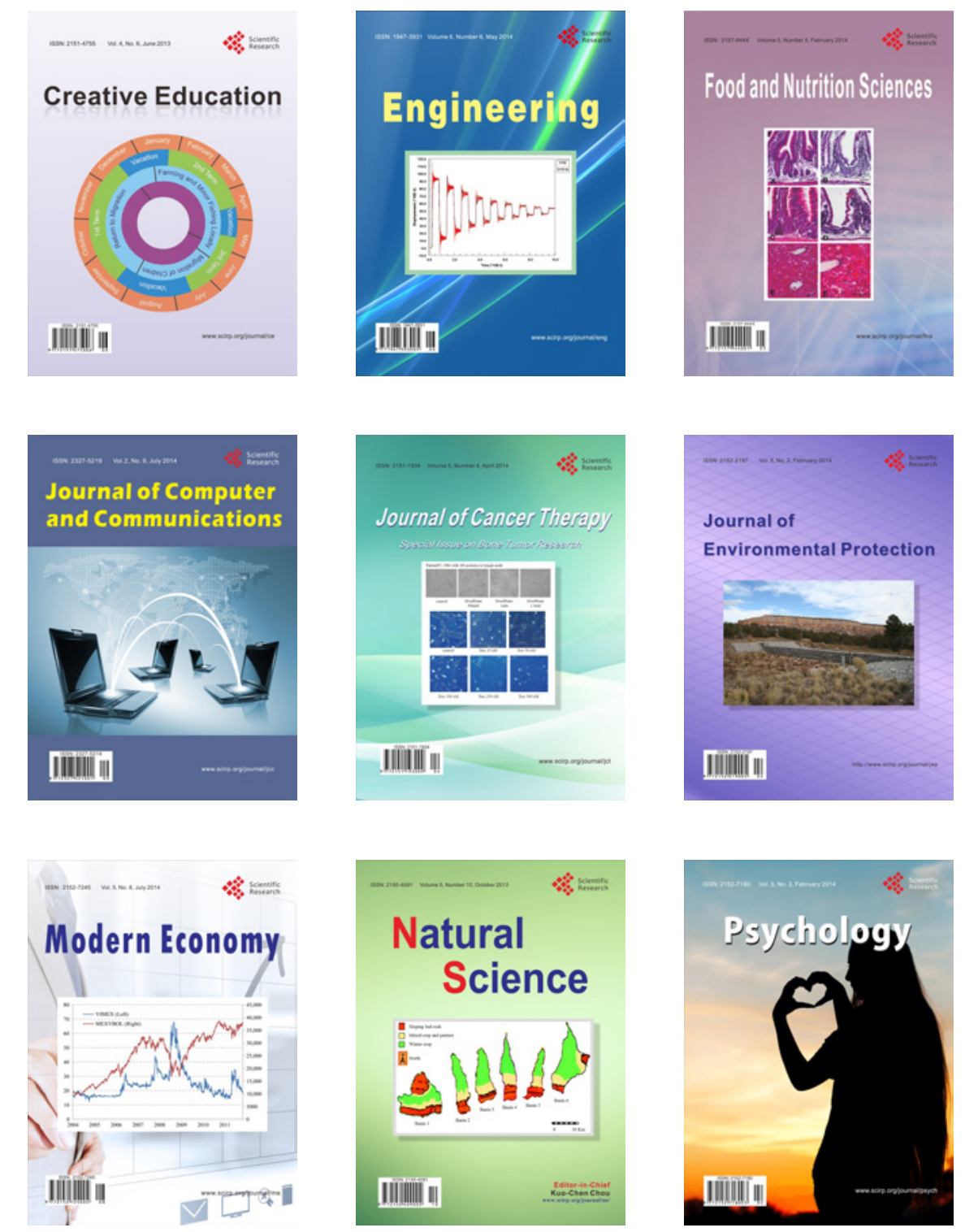